\title{
Oat Hulls as Addition to High Density Panels Production
}

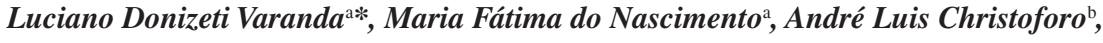 \\ Diogo Aparecido Lopes Silva ${ }^{\mathrm{c}}$, Francisco Antonio Rocco Lahr
}

\author{
${ }^{a}$ Department of Materials Engineering, University of São Paulo - USP, Av. Trabalhador São-carlense, \\ 400, Arnold Schimidt, CEP 13566-590, São Carlos, SP, Brazil \\ ${ }^{\mathrm{b}}$ Department of Mechanical Engineering, Federal University of São João del Rei-UFSJ, \\ Praça Frei Orlando, 170, Centro, CEP 36307-352, São João del Rei, MG, Brazil \\ ${ }^{c}$ Department of Production Engineering - SEP, University of São Paulo - USP, Av. Trabalhador \\ São-carlense, 400, Arnold Schimidt, CEP 13566-590, São Carlos, SP, Brazil \\ ${ }^{\mathrm{d}}$ Department of Structural Engineering - SET, University of São Paulo - USP, Av. Trabalhador \\ São-carlense, 400, Arnold Schimidt, CEP 13566-590, São Carlos, SP, Brazil
}

Received: December 18, 2012; Revised: June 7, 2013

\begin{abstract}
Wood-based panels have been widely used around the world in various segments of timber industry. Thus, alternative raw-materials have been systematically researched in order to reduce of wood demand in particleboard production. The aim of this work was to produce and evaluate particleboards of Eucalyptus grandis and oat hulls (Avena sativa), bonded under pressure with castor oil based polyurethane resin, in the proportion of $10 \%$ relative to the dry mass of the particles. The percentages of particles used per material were: Eucalyptus grandis 100, 85, 70 and $0 \%$ and oat hulls 0, 15, 30 and $100 \%$, respectively. Physical-mechanical performance of the panels produced was evaluated based on standards ABNT NBR 14810:2006 ${ }^{[1]}$ and BS EN 312:2003 ${ }^{[2]}$. By analysis of variance (ANOVA), the fraction of particles of Eucalyptus grandis was significant only in the modulus of rupture (MOR) in static bending. Panels produced with $100 \%$ oat hulls presented highest value of MOR.
\end{abstract}

Keywords: particleboard, Eucalyptus, waste recovery, analysis of variance (ANOVA)

\section{Introduction}

Wood panels manufacture show advantages of possibility to use alternative raw materials, as agro-industrial waste. Such products have increasing their importance, representativeness and use around the world, including Brazil, stimulated by the economic and environmental benefits of natural and renewable raw materials.

Considering wood-based panels from reconstituted wood, particleboard can be highlighted because it is the most consumed and produced worldwide (Brazilian Association of Wood Panels Industry - ABIPA) ${ }^{3}$. In Brazil, according to $\mathrm{ABIPA}^{3}$ particleboard represents about $50 \%$ of reconstituted panel manufacture and continues providing growth prospects for the next years. Particleboard is commonly used in furniture sector, mainly in the production of cupboard sides, dividers, shelves, tabletops, and also in buildings (e.g. wood floors) ${ }^{4}$.

At the same time, companies should adopt proactive strategies to control and predict the environmental burdens of their activities, providing better results in environmental performance. In this sense, Schweinle ${ }^{5}$ has highlighted wood panels because there are several relevant issues that require further developments, such as case study of alternative wood panels manufacture including agro-industrial waste as raw material. In Brazil, agro-industrial residues are

*e-mail: lu.varanda@sc.usp.br available in large volumes and have significant potential for employment. In particular, it is mentioned oats, food product usually consumed in the country and that generates an abundant volume of waste (oat hulls).

In this context, "green" materials were applied in this study, such as reforested wood from Eucalyptus grandis species, oat hulls (agro-industrial waste) from Avena sativa and polyurethane resin from castor oil.

The aim of this study is to evaluate physical-mechanical properties of particleboards made with Eucalyptus grandis particles and addition of oat hulls residue.

\section{Literature Review}

Brazil is the sixth largest producer of wood panels in the world, and the particleboard is one of main products (Brazilian Association of Producers of Reforested Forests - ABRAF) ${ }^{6}$.

Chipboard or particleboard can be produced from any lignocellulosic material and can give a high mechanical strength and predetermined specific gravity because of the lignocellulosic structure is similar to timber, according Rowell et al. .

In turn, Brazilian agro-industrial residues are available in large scale and have significant potential for employment. According Tamanini and $\mathrm{Hauly}^{8}$, agro-industrial waste 
generation is about 250 million tons/year. Among these residues, oat hulls have great potential, especially in relation to raw materials availability. The production of oats, the country, exceeded 500,000 tons in 2011 (Brazilian Commission of Research in Oat) ${ }^{9}$. According to Webster ${ }^{10}$, about $30 \%$ of oat production refers to oat hull, a byproduct of processing oat cereal that represents approximately 150,000 tons/year. Oats hulls have been discarded during grain processing, which become a pollutant source to the environment. Thus, it is necessary, essential and appropriate to establish alternatives for its reuse.

Amino resins are synthetic and thermosetting polymers mainly used in wood-based panels manufacture and ureaformaldehyde (UF) resin is one of the major commercial products $^{11}$, because its low cost and good technical performance. However, there are some key environmental problems of formaldehyde-based resins. Silva et al. ${ }^{12}$ highlighted environmental impacts of UF resin life cycle for ecotoxicity and human toxicity categories. Formaldehyde emissions are potentially carcinogenic and can cause effects on human health (e.g. nausea, watery eyes, nose and throat irritation). Thus, environmental benign alternatives to UF resin are desired. For this, was used castor oil based polyurethane resin (PU) that is from natural and renewable source.

PU resin from castor oil has been an alternative binder during wood panels manufacturing, as shown by Bertolini $^{13}$, Ferro ${ }^{14}$ and Jesus ${ }^{15}$, providing satisfactory technical performance. This bicomponente adhesive was originated in 1997, in the Institute of Chemistry of São Carlos, University of São Paulo, composed of polyol, extracted from castor beans, and prepolymer (isocyanate), resulting in polyurethane, which cure at temperature about $100{ }^{\circ} \mathrm{C}^{[15]}$.

Quality of wood-based panels is evaluated by their physical-mechanical properties such as modulus of elasticity (MOE) and modulus of rupture (MOR) in static bending, internal bond, density, water absorption, thickness swelling etc, according Iwakiri ${ }^{16}$.

Density is one factor that influences panel mechanical performance, and must be as uniform as possible along panel thickness to ensure uniformity properties. Particleboards are usually produced with density range from 600 to $700 \mathrm{~kg}$ / $\mathrm{m}^{3}$. According to Kelly ${ }^{17}$, a minimum amount of particles compaction is required to provide their consolidation during pressing cycle.

Iwakiri et al. ${ }^{18}$ produced high density particleboard and the results presented a significantly improvement in physical-mechanical properties (as more dimensional stability and better mechanical resistance). Melo et al. ${ }^{19}$ determined physical-mechanical properties of particleboard made from Eucalyptus grandis wood and rice husk and the results showed that rice husk addition provided greater dimensional stability and lower the strength of the panels. Bertolini et al. ${ }^{20}$ produced high density particleboards and the results of density were between 880 to $970 \mathrm{~kg} / \mathrm{m}^{3}$. So, variability in physical-mechanical performance of the panels produced with different type of material showed their different behaviors.

\section{Experimental Procedures}

\subsection{Particles production}

In panels manufacturing, were used particles of Eucalyptus grandis (apparent density of $640 \mathrm{~kg} / \mathrm{m}^{3}$ ) and oat hulls (apparent density of $290 \mathrm{~kg} / \mathrm{m}^{3}$ ). These particles were generated in a knifes mill, type Willye of Marconi brand MA 680 model, using $2.8 \mathrm{~mm}$ sieve opening.

Eucalyptus grandis was obtained from companies in the city and region of São Carlos - SP, while oat hulls (Avena sativa) were obtained from industry sector.

It was made a particle size analysis in order to determine its dimensions. SOLOTEST was the equipment used, with sieves of particle sizes that meet the specifications of ASTM corresponding to $7,10,16,30,40$ and 50 mesh. Also was used a balance of Marconi brand, model AS 5000C, with a sensitivity of 0.1 grams.

After generation of particles, a sample of 200 grams was removed for each material. These samples were subjected to vibration for ten minutes in vibration velocity 5 and allowing the material to cross the sieves in descending order of aperture. Three replicates were performed for each material. The particles that passed through the sieve of 50 mesh (sieve with smallest opening) were considered "fine".

The moisture content of the particles of both materials was $9 \%$. Figure 1 show the particles of both materials, before and after the milling process, and the mill used.

\subsection{Panels manufacturing}

Particleboards with one layer (homogeneous panels) of high density were produced. In this process were used castor oil based polyurethane resin (PU), bicomponent, 1:1 between prepolymer and poliol, with solids content of $100 \%$. The 1:1 proportion was used because the excellent performance achieved by researchers of the LaMEM (Wood and Timber Structures Laboratory) in studies using this proportion ${ }^{13,21}$. One of the components (polyol) is derived from vegetable oil with a density of $1.10 \mathrm{~g} / \mathrm{cm}^{3}$ and the other component (prepolymer) is the polyfunctional isocyanate with a density of $1.24 \mathrm{~g} / \mathrm{cm}^{3}$, both supplied by industry sector. This resin was used due to the excellent performance achieved in previous studies, developed in the LaMEM with wood panels ${ }^{13,22,14,23}$.

In each panel was used $640 \mathrm{~g}$ of particles, bonded with PU resin, in the proportion of $10 \%$ relative to the dry mass of the particles, in all treatments. We used this amount of particles per panel $(640 \mathrm{~g})$ to ensure that the panels stay with high density (above $800 \mathrm{~kg} / \mathrm{m}^{3}$ ), considering the density of each material used.

Parameters used in press cycle were: press pressure $4 \mathrm{MPa}$; press time 10 minutes; press temperature $100{ }^{\circ} \mathrm{C}$. Such parameters as well as the dimensions of the residues were evaluated by Dias $^{21}$. Figure 2 show the panels manufacturing.

The particles of both materials were weighed and mixed with glue for five minutes approximately. The glue machine used was Lieme, model BP-12 SL, how to present the Figure $2 \mathrm{~b}$. Then, the particles with glue were subjected to small press (about $0.013 \mathrm{MPa}$ ). The pre-pressing of the panel was performed by manual mechanical press own 
manufacturing (Figure 2c). The next step was the pressing of the panels, done in the semi-automatic press Marconi, model MA 098/50, how to present the Figure 2d. Finally, before 72 hours, necessary for full cure of the resin and reaches the moisture equilibrium with the environment, panels produced were correctly squaring, being removed $20 \mathrm{~mm}$ from each edge.

Particleboards were divided into groups according to the different proportions of each particulate material (Eucalyptus grandis and oat hulls). Table 1 shows factors and levels used for design experiments giving rise to four experimental conditions (EC), as shown in Table 2.

\subsection{Tests performed and results analysis}

For each experimental condition (EC), six panels with identical particles proportion were produced. In total, twenty-four panels produced with nominal dimensions: $280 \times 280 \times 10 \mathrm{~mm}$.

In each panel were removed one specimens for each property evaluated. The mechanical properties evaluated were modulus of elasticity (MOE) and modulus of rupture (MOR), both obtained by testing a three-point in static bending, and internal bond (tension perpendicular to the panel surface). The physical properties evaluated were density, water absorption, thickness swelling and

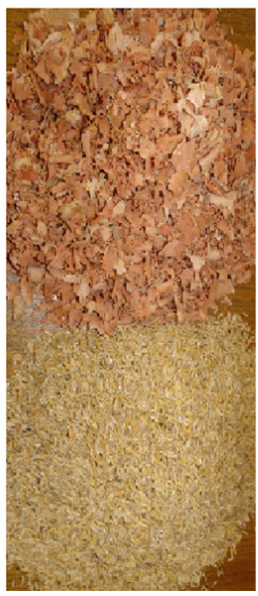

(a)

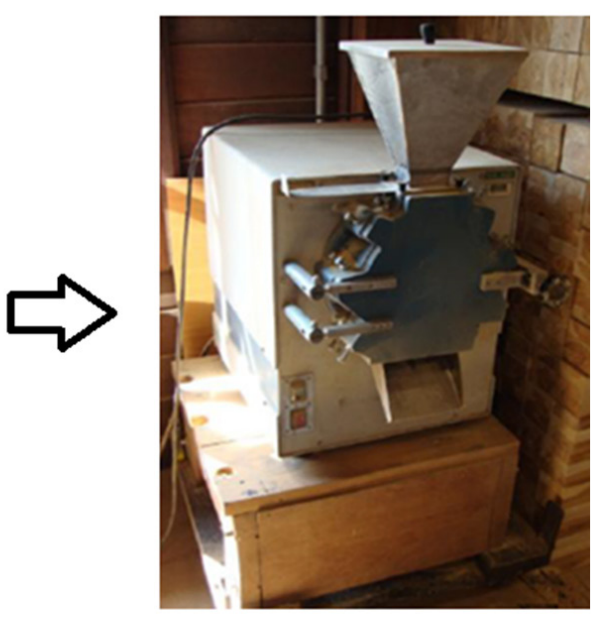

(b)

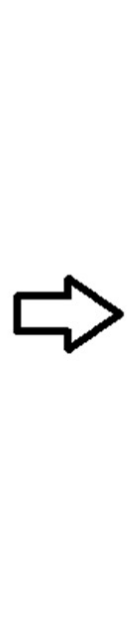

(c)

Figure 1. (a) Particles before to the milling process, (b) mill used, (c) particles after the milling process.

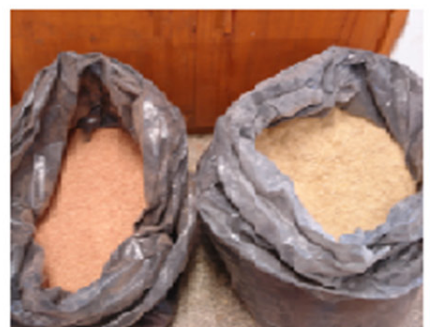

(a)

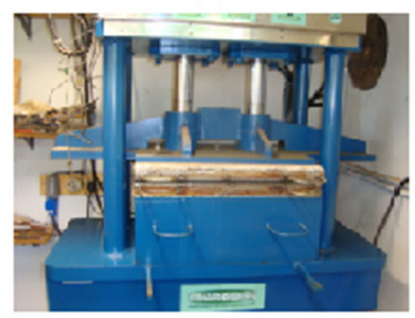

(d)

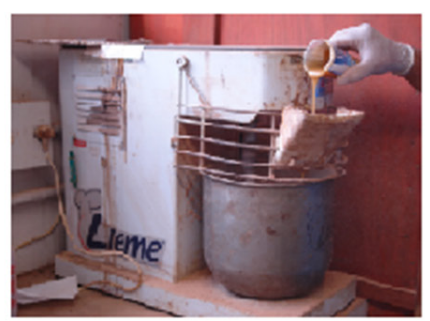

(b)

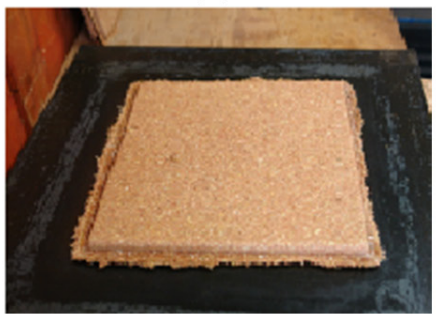

(e)

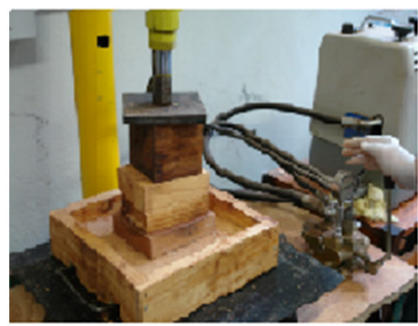

(c)

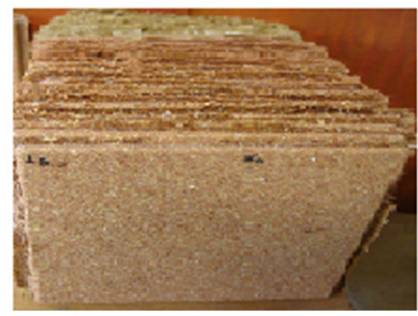

(f)

Figure 2. (a) Particles of both materials, (b) equipment that mixes the glue and particles, (c) pre-press (d) hydraulic press, (e) panel after pressing; (f) Panels produced. 
compaction ratio. Specimen dimensions as well as physical and mechanical tests were performed according to ABNT NBR 14810:2006 ${ }^{[1]}$. Figure 3 show the physical and mechanical tests performed.

The compaction ratio of the panels was calculated by the following relation: panel density by the density of the material which originated the particles.

The variance analysis (ANOVA) was used to investigate the influence of the fraction of particles of Eucalyptus grandis (compositions between particles of both materials) in the physical and mechanical properties of the panels produced. The significance level $(\alpha)$ was $5 \%$, considering the null hypothesis $\left(\mathrm{H}_{0}\right)$ the equivalence between the means and the non-equivalence as the alternative hypothesis $\left(\mathrm{H}_{1}\right)$. $\mathrm{P}$-value greater than the significance level involves accepting

Table 1. Factors and experimental levels.

\begin{tabular}{lcccc}
\hline \multicolumn{1}{c}{ Input Factors (\%) } & \multicolumn{4}{c}{ Experimental Levels } \\
\hline Eucalyptus grandis & 100 & 85 & 70 & 0 \\
Oat hulls & 0 & 15 & 30 & 100 \\
\hline
\end{tabular}

Table 2. Factors composition.

\begin{tabular}{cl}
\hline EC & \multicolumn{1}{c}{ Ratios constituents } \\
\hline 1 & $100 \%$ Eucalyptus grandis \\
2 & $(85 \%$ Eucalyptus grandis $-15 \%$ Oat hulls $)$ \\
3 & $(70 \%$ Eucalyptus grandis $-30 \%$ Oat hulls $)$ \\
4 & $100 \%$ Oat hulls \\
\hline
\end{tabular}

$\mathrm{H}_{0}$, rejecting it otherwise. In validation of the ANOVA model, normality test of Anderson-Darling and the Bartlett's testes to verify the homogeneity between variances were used, both at the $5 \%$ level of significance, considering the null hypotheses of the normality and of the equivalence between variances. The null hypothesis hypotheses be accepted if the P-value obtained in the tests are higher than the level of significance, rejecting them otherwise. Accused the significance of the factor by ANOVA, was used the Tukey test for grouping of the averages.

\section{Results and Discussion}

The Table 3 shows the results of particle size analysis.

As can be seen in Table 3, about $70 \%$ of the particles of Eucalyptus grandis and $75 \%$ of the particles of oat hulls were retained on sieves of 16 mesh $(1.190 \mathrm{~mm})$ and 30 mesh (0.595 mm). The material Eucalyptus grandis showed more "fine" that oat hulls.

Table 4 presents the average values per experimental condition (EC) for the response variables: MOE and MOR, internal bond (IB), density, water absorption (WA) and thickness swelling (TS).

It is noteworthy that ABNT NBR 14810:2006 ${ }^{[1]}$ establishes requirements for physical-mechanical properties of particleboards, except for the modulus of elasticity in bending (MOE). For the latter, requirements are established by BS EN 312:2003 ${ }^{[2]}$ standard.

Experimental values of MOE were obtained for samples ranged from 1654 to $2865 \mathrm{MPa}$. All values of MOE of panels met the requirement established by BS EN 312:2003 ${ }^{[2]}$
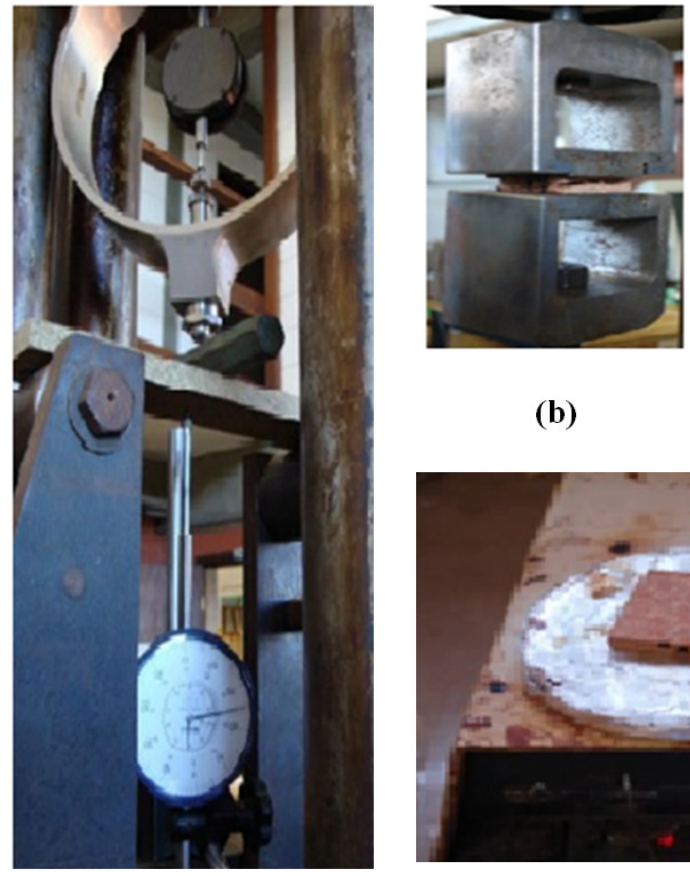

(b)

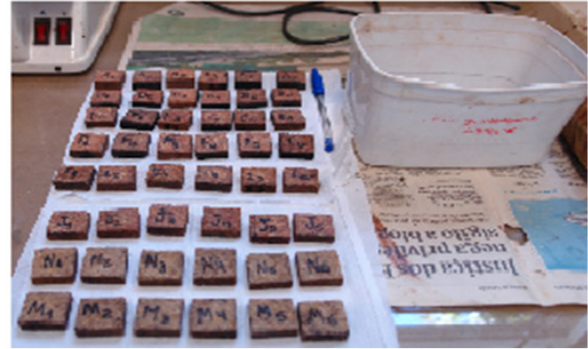

(c)

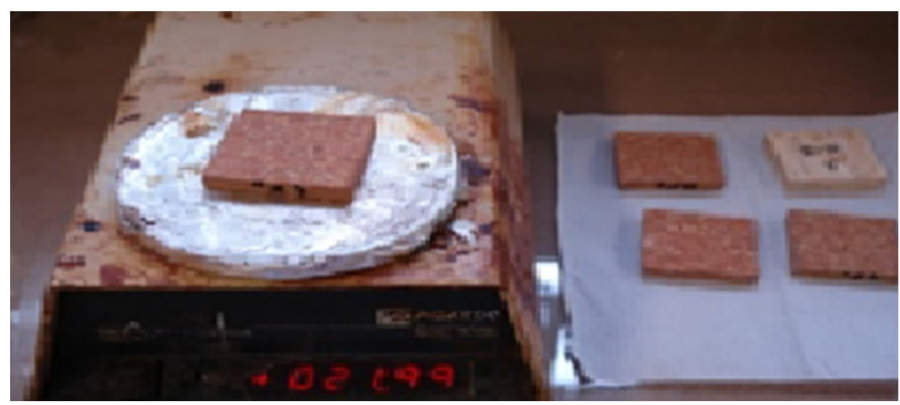

(a)

(d)

Figure 3. (a) Static bending test, (b) internal bond test, (c) water absorption and thickness swelling tests, (d) density test. 
Table 3. Mean values of particle size analysis.

\begin{tabular}{cccccc}
\hline Sieve $(\mathbf{m e s h})$ & Sieve opening $(\mathbf{m m})$ & Mass retained $(\mathrm{g})$ & Mass retained $(\%)$ & Mass retained $(\mathbf{g})$ & Mass retained $(\%)$ \\
\hline \multicolumn{7}{c}{ Eucalyptus } & grandis & Oat hulls \\
\hline 7 & 2.830 & 0.6 & 0.3 & 0.8 & 0.4 \\
10 & 2.000 & 13.1 & 6.5 & 13.4 & 6.7 \\
16 & 1.190 & 66.7 & 33.4 & 69.9 & 34.9 \\
30 & 0.595 & 73.0 & 36.5 & 80.7 & 40.4 \\
40 & 0.420 & 17.6 & 8.8 & 16.8 & 8.4 \\
50 & 0.297 & 11.0 & 5.5 & 7.4 & 3.7 \\
Finos $<50$ & $<0.297$ & 18.0 & 9.0 & 11.0 & 5.5 \\
Total & & 200.0 & 100.0 & 200.0 & 100.0 \\
\hline
\end{tabular}

Table 4. Mean values of response variables by experimental condition (EC).

\begin{tabular}{ccccccc}
\hline EC & MOE (MPa) & MOR (MPa) & IB (MPa) & WA (\%) & TS $(\%)$ & Density (kg/m $\left.{ }^{3}\right)$ \\
\hline 1 & 2349 & 18 & 1.84 & 5.2 & 4.3 \\
2 & 2366 & 18 & 1.65 & 5.9 & 4.2 \\
3 & 2342 & 20 & 1.74 & 6.0 & 5.5 & 941 \\
4 & 1942 & 24 & 1.60 & 6.8 & 4.2 \\
\hline
\end{tabular}

Table 5. Results of compaction ratio of the panels.

\begin{tabular}{ccc}
\hline EC & CR & VC (\%) \\
\hline 1 & 1.49 & 5.1 \\
2 & 1.60 & 6.9 \\
3 & 1.77 & 7.3 \\
4 & 3.50 & 3.3 \\
\hline
\end{tabular}

(minimum value of $2050 \mathrm{MPa}$ ), except the experimental condition 4 (Table 4).

In your study, Lee and $\mathrm{Kang}^{24}$ and Melo et al. ${ }^{19}$ have obtained similar results as the oat hulls factor in this study, that shows the phenomenon of reduced MOE as it increases the percentage of addition of other material.

The MOR property of the particleboards ranged from 13 and $30 \mathrm{MPa}$. All values of MOR of panels met the requirement established by standard ABNT NBR 14810:2006 ${ }^{[1]}$, with minimum value of $18 \mathrm{MPa}$ (Table 4). As this study, Bertolini et al. ${ }^{20}$ also obtained MOR values greater than $20 \mathrm{MPa}$, i.e. well above of the required value by ABNT NBR 14810:2006 [1].

It was observed that the MOR property increased as the added oat hulls, probably explained by the interphase region, noted of the chemical interaction between phases.

Internal bond property varied between $0.80 \mathrm{MPa}$ and 2.74 MPa. All values of internal bond of panels met the requirements established by standards ABNT NBR 14810:2006 ${ }^{[1]}$ and BS EN 312:2003 [2], with minimum values of 0,40 and $0,45 \mathrm{MPa}$, respectively. High values of internal bond are related to good interaction resin-particles. The results obtained for internal bond are similar to those obtained by Bertolini ${ }^{13}$.

There are no requirements for water absorption property $(2 \mathrm{~h})$ in the standards of particleboard. The results of water absorption ( $2 \mathrm{~h}$ ) obtained resemble those found by Bertolini ${ }^{13}$.

All results obtained for the thickness swelling (2h) were lower than of $8 \%$ stipulated by ABNT NBR 14810:2006 ${ }^{[1]}$, for panels with thickness between 8 and $13 \mathrm{~mm}$.

Compound density ranged between 797 and $1068 \mathrm{~kg} / \mathrm{m}^{3}$. Practically all panels classified as high-density. This large variation in panel's density (797 to $1068 \mathrm{~kg} / \mathrm{m}^{3}$ ), it was associated the large difference in density of the materials used.

The compaction ratio was not subjected to analysis of variance. Table 5 presents mean values of compaction ratio (CR) and variation coefficient (VC) for each of the four experimental conditions evaluated.

Mean values of compaction ratio ranged from 1.49 to 1.77 for the experimental conditions 1 to 3 , consistent with established by Maloney ${ }^{11}$ and Moslemi ${ }^{25}$. For the experimental condition 4 , the mean value of compaction ratio obtained (3.50) is consistent with the results of Mendes et al. ${ }^{26}$, that obtained values between 1.39 to 3.12. The variation coefficients (VC) obtained for the compression ratio are lower than $8 \%$, reflecting a small variation of this property between the panels evaluated.

Panels of experimental condition 4 presented higher density than panels of experimental condition 1 . It can be justified by lower apparent density of oat hulls particles $\left(290 \mathrm{~kg} / \mathrm{m}^{3}\right)$, a fact which provides greater accommodation in the material (higher compaction ratio), and consequently higher density to this panels.

Table 6 shows the results of normality tests and equivalence between variances (ANOVA) for each property.

Table 5, P-values of the Anderson-Darling and Bartlett tests were both higher than the level of significance, concluding be normal distributions and equal variances between treatments per response-variable, validating the ANOVA model. By analysis of variance, the fraction of particles of Eucalyptus grandis was significant only in 
Table 6. Results of Anderson-Darling, Bartlett and ANOVA.

\begin{tabular}{lcccc}
\hline Response variables & $\begin{array}{c}\text { P-value } \\
\text { (Anderson-Darling) }\end{array}$ & $\begin{array}{c}\text { P-value (Bartlett) } \\
\text { P-value (ANOVA) }\end{array}$ & \multicolumn{2}{c}{$\begin{array}{c}\text { Degrees of } \\
\text { freedom (ANOVA) }\end{array}$} \\
\hline MOR & 0,384 & 0,878 & 23 & 23 \\
MOE & 0,864 & 0,553 & 23 & 23 \\
IB & 0,106 & 0,211 & 0,086 \\
Density & 0,583 & 0,460 & 23 & 0,101 \\
TS (2h) & 0,814 & 0,271 & 0,03 & 23 \\
WA (2h) & 0,953 & 0,705 & 0,358 \\
\hline
\end{tabular}

Table 7. Results of the Tukey test.

\begin{tabular}{ccccc}
\hline \multicolumn{5}{c}{ MOR (MPa) } \\
\hline & $\mathbf{1 0 0 \%}$ & $\mathbf{8 5 \%}$ & $\mathbf{7 0 \%}$ & $\mathbf{0 \%}$ \\
\hline $\bar{x}$ & 18,17 & 17,16 & 19,90 & 24,52 \\
Grouping & $\mathrm{B}$ & $\mathrm{B}$ & $\mathrm{AB}$ & $\mathrm{A}$ \\
\hline
\end{tabular}

the modulus of rupture in static bending $(\mathrm{P}$-value $<0.05)$, providing equivalent results between treatments stipulated for other assessed properties. Table 7 presents the results of grouping by Tukey test for MOR.

In Table 7, the highest value of the MOR was derived from the panels produced with $100 \%$ oat hulls, and was equivalent to the composition of particles between $70 \%$ Eucalyptus grandis and $30 \%$ oat hulls. The lowest values were derived from the condition with $85 \%$ of the particles of Eucalyptus grandis and $15 \%$ oat hulls, and this condition was equivalent to the composition with $100 \%$ Eucalyptus grandis.

\section{Conclusions}

From the results it can be concluded that:

- Mean values to physical-mechanical properties evaluated met the requirements established by

\section{References}

1. Associação Brasileira de Normas Técnicas-ABNT. NBR14810: chapas de madeira aglomerada. Rio de Janeiro: ABNT; 2006.

2. British Standard. EN 312: Particleboards - specifications. London; 2003.

3. Brazilian Association of Wood Panels Industry - ABIPA. Números do setor em 2012. Available from: <http://www.abipa. org.br/numeros.php>. Access in: 20/04/2012.

4. Biazus A, Hora AB and Leite BGP. Panorama de mercado: painéis de madeira. BNDES Setorial. 2010; 32:49-90.

5. Schweinle J. Wood \& other renewable resources: a challenge for LCA. International Journal of Life Cycle Assessment. 2007; 12:141-142.

6. Brazilian Association of Producers of Reforested Forests - ABRAF. Anuário Estatístico ABRAF 2012 - Ano Base 2011. Available from: <http://www.abraflor.org.br/ estatisticas.asp >. Access in: 06/05/2013.

7. Rowell RM, Han JS, Rowell JS. Characterization and Factors Affecting Fiber Properties. In: Frollini E, Leão AL and Mattoso LHC, edsitors. Natural Polymers and Agrofibers Based Composites. São Carlos: Embrapa Instrumentação standards ABNT NBR 14810:2006 ${ }^{[1]}$ and BS EN 312:2003 ${ }^{[2] ;}$

- Proportion of resin used (10\%) proved to be sufficient, as it responded to requirements of national and international standards cited;

- Progressive insertion of oat hulls was responsible for increasing MOR, conducting the greatest value for composition to $100 \%$ oat hulls;

- The compaction ratio ranged between 1.49 to 3.50 for the panels produced;

- By analysis of variance, the fraction of particles of Eucalyptus grandis was significant only in the MOR in static bending;

- The highest value of the MOR was obtained from the panels produced with $100 \%$ oat hulls, and the lowest values were derived from the condition with $85 \%$ of the particles of Eucalyptus grandis and $15 \%$ oat hulls.

\section{Acknowledgements}

The authors would like to thank The São Paulo Research Foundation (FAPESP) - for the scholarships granted and support research.

Agropecuária; 2000. Section II - Agrofibers Composites, p. $115-134$.

8. Tamanini C and Hauly MCO. Resíduos agroindustriais para produção biotecnológica de xilitol. Ciências Agrárias. 2004; 25(4):315-330.

9. Brazilian Commission of Research in Oat. $30^{a}$ Meeting. Available from: <http://www6.ufrgs.br/agronomia/aveia $>$. Access in: 22/06/2010.

10. Webster FH. Oats. In: Henry RJ and Kettlewell PS, edsitors. Cereal grain quality. Atlanta; 1996. p. 179-203.

11. Maloney TM. Modern particleboard and dry-process fiberboard manufacturing. San Francisco: Miller Freeman; 1993.

12. Silva DAL, Mendes NC, Varanda LD, Ometto AR and Rocco Lahr FA. Life cycle assessment of urea formaldehyde resin: comparison by CML (2001), EDIP (1997) and USEtox (2008) methods for toxicological impact categories. In: Nee AYC, Song B and Ong SK, editors. Re-engineering Manufacturing for Sustainability: Proceedings of the 20th CIRP. Singapore: Springer; 2013. p. 529-534.

13. Bertolini MS. Emprego de resíduos de Pinus sp tratado com preservante CCB na produção de chapas de partículas 
homogêneas utilizando resina poliuretana à base de mamona. [Dissertação]. São Carlos: Universidade de São Paulo; 2011.

14. Ferro FS. Painéis OSB com madeira Schizolobium amazonicum e resina poliuretana à base de óleo de mamona: viabilidade técnica de produção. [Dissertação]. São Carlos: Universidade de São Paulo; 2013.

15. Jesus JMH. Estudo do adesivo poliuretano à base de mamona em madeira laminada colada (MLC). [Tese]. São Carlos: Universidade de São Paulo; 2000.

16. Iwakiri S. Painéis de madeira reconstituída. Curitiba: Fundação de Pesquisas Florestais do Paraná; 2005.

17. Kelly MW. A critical literature review of relationship between processing parameters and physical properties of particleboard. USDA. Forest Service. Forest Products Laboratory General Technical Report. 1977; (10):1-66.

18. Iwakiri S, Andrade AS, Cardoso Junior AA, Chipanski ED, Prata JG and Adriazola MKO. Produção de painéis aglomerados de alta densificação com uso de resina melaminauréia-formaldeído. Cerne. 2005; 11(4):323-328.

19. Melo RR, Santini EJ, Haselein CR and Stangerlin DM. Propriedades físico-mecânicas de painéis aglomerados produzidos com diferentes proporções de madeira e casca de arroz. Ciência Florestal. 2009; 19(4):449-460.
20. Bertolini MS, Lahr FAR, Nascimento MF, Agnelli JAM. Accelerated Artificial Aging of Particleboards from Residues of CCB Treated Pinus sp. and Castor Oil Resin. Materials Research. 2013; 16(2):293-303. http://dx.doi.org/10.1590/ S1516-14392013005000003

21. Dias FM. Aplicação de resina poliuretana à base de mamona na fabricação de painéis de madeira compensada e aglomerada. [Tese]. São Carlos: Universidade de São Paulo; 2005.

22. Campos CI. Produção e caracterização físico-mecânica de MDF a partir de fibras de madeira de reflorestamento $e$ adesivos alternativos em diferentes teores. [Tese]. São Carlos:Universidade de São Paulo; 2005.

23. Souza AM. Produção e avaliação do desempenho de painéis de partículas orientadas (OSB) de Pinus sp com inclusão de telas metálicas. [Dissertação]. São Carlos: Universidade de São Paulo; 2012.

24. Lee HH and Kang CW. Development of rice hull insulation board using urea formaldehyde resin. Mokchae Konghak. 1998; 26(4):50-55.

25. Moslemi AA. Particleboard. London: Southern Illinois University Press; 1974.

26. Mendes RF, Abranches RAS, Santos RC and Guimarães JB Jr. Painéis aglomerados produzidos com bagaço de cana em associação com madeira de eucalipto. Scientia Forestalis. 2010; 38(86):285-295. 